\title{
Correction: Assessing the global reach and value of a provider-facing healthcare app using large-scale analytics
}

O'Reilly-Shah V, Easton G, Gillespie S. Assessing the global reach and value of a provider-facing healthcare app using large-scale analytics. BMJ Glob Health 2017;2:e000299. The below acknowledgements section should be included in this article:

Acknowledgements Supported by the National Center for Advancing Translational Sciences of the National Institutes of Health under Award number UL1TR002378. The content is solely the responsibility of the authors and does not necessarily represent the official views of the National Institutes of Health.

Open Access This is an Open Access article distributed in accordance with the Creative Commons Attribution Non Commercial (CC BY-NC 4.0) license, which permits others to distribute, remix, adapt, build upon this work non-commercially, and license their derivative works on different terms, provided the original work is properly cited and the use is non-commercial. See: http://creativecommons.org/licenses/by-nc/4.0/

(C) Article author(s) (or their employer(s) unless otherwise stated in the text of the article) 2017. All rights reserved. No commercial use is permitted unless otherwise expressly granted.

BMJ Glob Health 2017;2:e000299corr1. doi:10.1136/bmjgh-2017-000299corr1

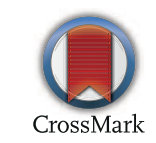

